\title{
Response of a kleptoplastidic foraminifer to heterotrophic starvation: photosynthesis and lipid droplet biogenesis
}

\author{
Jauffrais Thierry ${ }^{1,2, *}$, Lekieffre Charlotte ${ }^{1}$, Schweizer Magali ${ }^{1}$, Jesus Bruno ${ }^{3}$, Metzger Edouard ${ }^{1}$, \\ Geslin Emmanuelle ${ }^{1}$
}

${ }^{1}$ UMR CNRS 6112 LPG-BIAF, Bio-Indicateurs Actuels et Fossiles, Université d'Angers, 2 Boulevard Lavoisier, 49045 Angers CEDEX 1, France

2 Ifremer, RBE/LEAD, 101 Promenade Roger Laroque, 98897 Nouméa, New Caledonia

${ }^{3}$ EA2160, Laboratoire Mer Molécules Santé, Université de Nantes, Nantes, France

*Corresponding author : Thierry Jauffrais, email address : thierry.jauffrais@ifremer.fr

\begin{abstract}
:
The aim of this work is to document the complex nutritional strategy developed by kleptoplastic intertidal foraminifera. We study the mixotrophic ability of a common intertidal foraminifer, E. williamsoni, by (1) investigating the phylogenetic identity of the foraminiferal kleptoplasts, (2) following their oxygenic photosynthetic capacity, and (3) observing the modification in cellular ultrastructural features in response to photoautotrophic conditions. This was achieved by coupling molecular phylogenetic analyses and TEM observations with non-destructive measurements of kleptoplast $\mathrm{O} 2$ production over a 15-day experimental study. Results show that the studied E. williamsoni actively selected kleptoplasts mainly from pennate diatoms and had the ability to produce oxygen, up to $13.4 \mathrm{nmol} O 2 \mathrm{cell}-1 \mathrm{~d}-1$, from low to relatively high irradiance over at least 15 days. Ultrastructural features and photophysiological data showed significant differences over time, the number of lipid droplets, residual bodies and the dark respiration increased; whereas, the number of kleptoplasts decreased accompanied by a minor decrease of the photosynthetic rate. These observations suggest that in $\mathrm{E}$. williamsoni kleptoplasts might provide extra carbon storage through lipid droplets synthesis and highlight the complexity of E. williamsoni feeding strategy and the necessity of further dedicated studies regarding mechanisms developed by kleptoplastidic foraminifera for carbon partitioning and storage.
\end{abstract}

Keywords : foraminifera, electron microscopy, DNA barcoding, kleptoplasty, lipids 


\section{Introduction}

Kleptoplastidy (i.e. stealing plastids) is a form of symbiosis where only the chloroplasts from the algal food sources are sequestered by a host organism, without other algal organelles theoretically retained (Clark et al., 1990). In kleptoplastidic foraminifera, as observed in other kleptoplastidic organisms (Green et al., 2000, Nagai et al., 2008, Hansen et al., 2016), it is 
thought that the diatom nucleus is digested shortly after ingestion (i.e. within a few days?); whereas, chloroplasts (i.e. kleptoplasts) are kept longer, from days to many months (Correia \& Lee, 2000, Grzymski et al., 2002, Jauffrais et al., 2016). However, the chloroplast photosynthetic efficiency is strongly dependent on plastid photo-regulation capacities and on the synthesis of photosynthetic proteins, which are mainly synthetized and regulated from nuclear DNA genes in photosynthetic organisms (reviewed in Müller et al. 2001). In kleptoplastidic intertidal foraminifera, a part of the photosynthetic machinery is susceptible to photo-damage after light exposure at low tide in the absence of active photo-protective mechanisms and of nuclear genes encoding photosynthetic proteins. Thus, kleptoplast functionality inside a host cell is partially linked to the host's capacity for photo-regulating light exposure and maintaining active photo-protection mechanisms. In this context, kleptoplasts photo-damage might be avoided either by kleptoplasts physiological photoregulation mechanisms (e.g., xanthophyll cycle) or by behavioural responses of the host (Jesus et al., 2010, Cruz et al., 2015, Jauffrais et al., 2017). Behavioural responses for benthic foraminifera could be migrating into the sediment (Moodley et al., 1998, Geslin et al., 2004) or building cysts (Heinz et al., 2005, Jauffrais et al., 2016) to avoid excessive ambient light, strategies similar to what is observed in microphytobenthic pennate diatoms (Jesus et al., 2006, Mouget et al., 2008, Perkins et al., 2010).

Foraminiferal kleptoplast functions and characteristics are still poorly understood and therefore their role in biogeochemical cycles and in the foraminiferal metabolism needs clarifications (Jauffrais et al., 2019, LeKieffre et al., 2018b). Previous research has shown that these kleptoplasts originate from microalgae, essentially diatoms (Pillet et al., 2011). Their ultrastructure, origin, retention time and abundance are well documented in several species of foraminifera (Lopez, 1979, Lee et al., 1988, Cedhagen, 1991, Bernhard \& Bowser, 1999, Correia \& Lee, 2000, Correia \& Lee, 2002, Correia \& Lee, 2002, Goldstein et al., 2004, Pillet et al., 2011, Tsuchiya et al., 2015, Jauffrais et al., 2018). However, their maintenance, biological and ecological functions are not clearly defined yet (Lopez, 1979, Grzymski et al., 2002, Jauffrais et al., 2016, Cesbron et al., 2017).

Photosynthetic activity has been demonstrated in only a few kleptoplastidic foraminiferal species from intertidal mudflats (Lopez, 1979, Lee et al., 1988, Jauffrais et al., 2016, Cesbron et al., 2017, LeKieffre et al., 2018b). In Elphidium williamsoni the photosynthetic machinery was found to be functional (carbon assimilation), with kleptoplasts keeping their functionality up to several days and showing higher inorganic carbon uptake rate (5 times more) than Haynesina germanica (Lopez, 1979). 
The objectives of the current work are then to investigate the mixotrophic ability of a common intertidal foraminifer, E. williamsoni, by (1) investigating the phylogenetic identity of the foraminiferal kleptoplasts, (2) following their oxygenic photosynthetic capacity, and (3) observing the modification in cellular ultrastructural features in response to photoautotrophic culture conditions (i.e., without addition of heterotrophic food source).

In this context, we have coupled molecular identification (DNA barcoding) with TEM ultrastructure observations of E. williamsoni and $\mathrm{O}_{2}$ profiling (a non-invasive technique to measure photosynthesis).

\section{Materials and methods}

\section{Sampling site and specimen selection}

Surface sediment samples ( $0-0.5 \mathrm{~cm}$ depth, salinity 35) with live specimens of $E$. williamsoni were collected at low tide, during daytime, from a tidal mudflat on the Isle of Ré $\left(46^{\circ} 13^{\prime} 22.3^{\prime \prime} \mathrm{N} 1^{\circ} 30^{\prime} 46.7^{\prime \prime} \mathrm{W}\right.$, Bay of Biscay, France). The collected sediment was kept in ambient seawater in darkness, transported the next day to the laboratory, and then carefully and immediately sieved over 500 and $150 \mu \mathrm{m}$ meshes using artificial sea water (ASW, red Sea ${ }^{\circledR}$ salt in MilliQ ${ }^{\circledR}$ water at salinity 35). Within the same day, the fraction between 150 and $500 \mu \mathrm{m}$ was recovered and observed under a stereomicroscope to collect living E. williamsoni adult specimens. Live individuals were selected according to the colour of their cytoplasm (i.e. brown-green cytoplasm throughout all the chambers except the last one). Then, the selected foraminifera were checked for vitality by placing them overnight in glass Petri dishes in darkness with a small amount of autoclaved sieved sediment $(<38 \mu \mathrm{m})$ and ASW. The next day, only individuals showing clear signs of activity were selected for the experiment and for kleptoplast phylogenetic identification. These selected specimens were cleaned individually with a fine brush and rinsed several times with ASW to minimize external bacterial and microalgal contaminations and placed straightaway into experimental conditions.

Foraminiferal and kleptoplast molecular identification

Two cleaned specimens of E. williamsoni ( $\operatorname{Re} 021$ and $\mathrm{Re} 024)$ were selected for DNA analyses. They were air-dried for imaging with an environmental scanning electron microscope (eSEM, EVO LS10, ZEISS, Oberkochen, Germany) and total DNA was individually extracted (Pawlowski, 2000, Schweizer et al., 2005) from both specimens for foraminiferal, eukaryotic and chloroplast/bacterial identifications based on specific primer sets amplifying fragments of the SSU rDNA gene. 
To amplify foraminiferal DNA, a first PCR was performed with s14F3 and J2 primers followed by a nested PCR with primers s14F1 and N6 (Pawlowski, 2000, Darling et al., 2016).

For other organisms' DNA, two separate amplifications were done on the foraminiferal extraction using two primer sets; the first one targeted chloroplast/bacterial rDNA SSU (16S) with primers PLA491F and OXY1313R (West et al., 2001, Fuller et al., 2006) and the second one targeted eukaryotic nuclear rDNA SSU (18S) with primers DiatSSUF and DiatSSUR (Pillet et al., 2011). The 16S and 18S amplifications were then cloned for both foraminiferal specimens and 20 clones of each amplification (i.e. Re021-16S, Re021-18S, Re024-16S, Re024-18S) were sequenced. PCR amplification and cloning steps are described in detail in Jauffrais et al. (2019).

The two foraminiferal amplifications were sequenced directly with the Sanger method at GATC Biotech (Cologne, Germany) and clones of 16S and 18S rDNA (40 clones each) were sequenced with the same method. DNA sequences were then compared with BLAST (Basic Local Alignment Search Tool, blast.ncbi.nlm.nih.gov (Altschul et al., 1997)) for taxonomic identification. All sequences have been deposited in GenBank (Table 1 and Tables SI 1and 2). To identify more accurately sequences of diatom origin, two alignment sets were created in Seaview v.4 (Gouy et al., 2010) with a representative selection of sequences taken from GenBank for diatom $16 \mathrm{~S}$ and $18 \mathrm{~S}$ rDNA sequences, respectively. The sequences were automatically aligned with MUSCLE (Edgar, 2004, Edgar, 2004), implemented in Seaview, and corrected manually. Molecular phylogenetic trees were built with the PHYML program (Guindon \& Gascuel, 2003) implemented in Seaview, choosing the GTR (General Time Reversible) evolutionary model (Tavaré, 1986) and the aLRT (approximate Likelihood Ratio Test) branch support (Anisimova \& Gascuel, 2006). For the 16S analysis, 840 sites out of 879 present in the alignment were selected for the phylogenetic analysis; $73.1 \%$ of these sites had no polymorphism. For the $18 \mathrm{~S}$ analysis, 835 sites out of 1477 present in the alignment were selected for the phylogenetic analysis; $45.3 \%$ of these sites had no polymorphism.

\section{Experimental design}

Experiments to assess the oxygenic photosynthetic efficiency and ultrastructure features were made in a $18{ }^{\circ} \mathrm{C}$ temperature controlled room, in ASW (salinity 35) with a Light:Dark cycle of 6:18h. This photoperiod is based on the hypothesis that in the upper sediment layer and in turbid environments such as intertidal mudflat systems, E. williamsoni only has access to light during diurnal low tides. All selected foraminiferal specimens $(n=90)$ were spread in 18 Petri dishes ( 5 specimens per Petri dish) filled with $5 \mathrm{~mL}$ of ASW. The 90 specimens were placed 
under similar light conditions (50 $\mu \mathrm{mol}$ photons $\left.\mathrm{m}^{-2} \mathrm{~s}^{-1}\right)$ with Light:Dark cycle of 6:18h. Three replicates of five specimens (i.e. three Petri dishes) were then sampled for experimental purposes after $0,1,2,5,9$ and 15 days. During the experiment, the ASW was replaced every two days.

\section{Oxygen profiling and photosynthetic activity}

Clark-type oxygen microelectrodes of $50 \mu \mathrm{m}$ in diameter (Revsbech, 1989) (OX-50 Unisense, Denmark) were used to measure $\mathrm{O}_{2}$. The microelectrodes were calibrated using a solution of sodium ascorbate at $0.1 \mathrm{M}(0 \%)$ and ASW saturated in $\mathrm{O}_{2}(100 \%)$. Foraminiferal photosynthesis and $\mathrm{O}_{2}$ respiration rates were measured in a micro-tube made from Pasteur glass pipette tips with an inner diameter of $1 \mathrm{~mm}$. The micro-tube was fixed to a small vial filled with ASW (salinity 35), which was placed in an aquarium kept at $18^{\circ} \mathrm{C}$. A small pipette was used to position a pool of five specimens (i.e. one experimental replicate) in the microtube after removing air bubbles. Oxygen micro-profiles started at a distance of $200 \mu \mathrm{m}$ above the foraminifera and, when the gradient of $\mathrm{O}_{2}$ profiles was considered visually linear and stable, the measurements were registered and repeated five times, using $50 \mu \mathrm{m}$ steps until a distance of $650 \mu \mathrm{m}$ from the foraminifera. The oxygen flux (J) was then calculated using the first Fick's law (Li \& Gregory, 1974) to finally obtain the cell specific rate $\left(\mathrm{nmol} \mathrm{O}\right.$ cell $\left.^{-1} \mathrm{~d}^{-1}\right)$ as previously described (Høgslund et al., 2008, Geslin et al., 2011, Jauffrais et al., 2016).

Six different light steps were used to measure the $\mathrm{O}_{2}$ production and the dark respiration rate $\left(0,25,50,100,200,300\right.$ and $600 \mu \mathrm{mol}$ photons $\left.\mathrm{m}^{-2} \mathrm{~s}^{-1}\right)$. Photosynthetic activity $\mathrm{P}(\mathrm{I})$ data of $E$. willamsoni were fitted with a modified equation of Platt et al. (1980).

$$
P(\mathrm{I})=\mathrm{Pm} \times\left(1-\mathrm{e}^{\left(-\alpha \times \frac{\mathrm{I}}{\mathrm{Pm}}\right)}\right)-\mathrm{Rd} \quad \text { eq. } 1
$$

Where Pm is the maximum photosynthetic rate in the absence of inhibition ( $\mathrm{nmolO}_{2}$ cell $\left.^{-1} \mathrm{~d}^{-1}\right)$, $\mathrm{Rd}$ is the dark respiration rate of oxygen $\left(\mathrm{nmolO}_{2}\right.$ cell $\left.^{-1} \mathrm{~d}^{-1}\right)$ and alpha $(\alpha)$ the initial slope of the $\mathrm{P}(\mathrm{I})$ curve at limiting irradiance. The half-saturation constant Ek and the compensation irradiance Ic ( $\mu \mathrm{mol}$ photons $\mathrm{m}^{-2} \mathrm{~s}^{-1}$ ) were calculated according to Eqs. (2) and (3).

$$
\begin{gathered}
E k=\frac{\mathrm{Pm}-\mathrm{Rd}}{\alpha} \quad \text { eq. } 2 \\
I c=\frac{\mathrm{Ek} \times \mathrm{Rd}}{\mathrm{Pm}-\mathrm{Rd}} \quad \text { eq. } 3
\end{gathered}
$$


Following the oxygen profiling, the foraminifera were immediately collected, and chemically and individually fixed with a solution containing $4 \%$ glutaraldehyde and $2 \%$ paraformaldehyde in ASW at salinity 35. The samples were first kept at room temperature $\left(18-20^{\circ} \mathrm{C}\right)$ for $24 \mathrm{~h}$ and then placed at $4^{\circ} \mathrm{C}$ until processing.

For the TEM analyses, five specimens for each sampling time (days 0, 1, 2, 5, 9, 15) were prepared as described in LeKieffre et al. (2018b). The specimens were rinsed in ASW, decalcified in two successive baths of $0.1 \mathrm{M}$ EDTA $(1$ and $24 \mathrm{~h})$, and post-fixed with $2 \%$ osmium tetroxide for one hour. Foraminifera were then dehydrated with successive ethanol baths and embedded in LR White ${ }^{\circledR}$ resin. Ultrathin sections $(70 \mathrm{~nm})$ were cut using an ultramicrotome (Reichert Ultracut S, Leica, Germany) and placed on slot copper grids coated with a formvar-carbon film. Prior to observation, sections were stained with uranyl acetate (10 min, $2 \%$ aqueous uranyl acetate). The ultrathin sections were observed at the University of Angers (SCIAM) with a JEM-1400 (JEOL, Japan) TEM at an acceleration voltage of $120 \mathrm{kV}$.

For all specimens, the study focused on chambers located in the external (between $n-5$ to $n-$ 8) or internal (between $n-12$ and $n-17 ; n$ being the youngest chamber next to the aperture) foraminiferal whorl. The integrity of the mitochondria of all the specimens was checked to ensure the vitality of the studied specimens (Bernhard, 2000, Nomaki et al., 2016).

\section{Image and data analysis}

The different TEM micrographs were first merged on Photoshop (Adobe Systems, USA) to have the entire chambers imaged at magnification $\times 15000$. Then the total areas of each chamber and of kleptoplasts, lipid droplets and residual bodies were measured using the ImageJ software (Schneider et al., 2012).

Data were expressed as mean \pm standard deviation (SD). Following an examination of homogeneity of variance and normal distribution, ANOVA were performed and differences were considered significant at $p(\alpha=0.05)<0.05$. A one-way ANOVA was used to assess the effect of time (days $0,2,5,9,15$ ) on photophysiological parameters and a multi-factor ANOVA was used to assess effects of time (days $0,9,15$ ) and foraminiferal chamber location (outer $v s$ internal whorl), as well as the interaction (time/chamber location) on ultrastructural features. Fisher's least significant difference (LSD) tests were then applied to determine which experimental conditions were significantly different. Statistical analyses were carried out using Statgraphics Centurion XV.I (StatPoint Technologies, Inc., USA). 


\section{Results}

\section{Foraminifer and kleptoplast identification}

The morphospecies Elphidium williamsoni has been formally linked to the phylotype S1 (Darling et al., 2016) with DNA sequencing of topotypic specimens (Roberts et al., 2016). The two sequenced specimens ( $\operatorname{Re} 021$ and $\operatorname{Re} 024)$ from the Isle of Ré belong to the phylotype S1 (Table 1), confirming the morphological determination.

Among the 40 sequenced clones of $16 \mathrm{~S}$ rDNA, three were negative, one was a chimaera, three were of bacterial origin and 33 belonged to diatomaceous chloroplasts with a 98-99\% BLAST identity to chloroplasts of several diatom genera (Table SI 1, Fig. 1A). The phylogenetic analysis distributed diatom chloroplast sequences in nine clades (Fig. 1A): (1) one sequence closely related to Coscinodiscus, (2) four sequences belonging to Thalassiosirales, (3) two sequences close to Extubocellulus, (4) nine sequences close to Entomoneis and Amphora, (5) one sequence close to Dickieia, (6) five sequences close to Fragilaria and Nanofrustulum, (7) three sequences close to Asterionellopsis, (8) one sequence not clearly settled and (9) seven sequences belonging to Bacillariales. As the BLAST identification of the 16S SSU rDNA is not sufficient to identify accurately the sequences at the species or even the genus level, the sequenced clones of eukaryotic 18S rDNA were used to refine our identification. From the 39 sequenced clones of $18 \mathrm{~S}$ (Table SI 2, Fig. 1B), one was negative, one belonged to Viridiplantae (Cucurbitaceae), 13 to Fungi and 24 to Bacillariophyta (diatoms). Among the 24 diatomaceous sequences, there was no $100 \%$ similarity with BLAST, nevertheless most sequences could be identified at the generic level (Fig. 1B). Thirteen sequences could be attributed to the genus Nitzschia (98\% identity with BLAST), three to Frustulia (94\% identity), two to an unsequenced Gyrosigma species (93-95\% identity), two to Cocconeis (97\% identity) and three were respectively 99\% identical to species of the genera Achnanthes, Petrodictyon and Surirella. Another sequence was related to Gyrosigma/Pleurosigma (93\% identity).

General ultrastructural observations by TEM of E. williamsoni (Day 0)

Numerous small vacuoles (i.e., 5-20 $\mu \mathrm{m}$ diameter) were observed mainly in the youngest chambers (n to n-6) of E. willamsoni, and the number of vacuoles seemed to decrease in older chambers (Fig. 2B). Most kleptoplasts were well preserved with pyrenoid, lamella, girdle lamella and thylakoids clearly distinguishable (Fig. 3A) and were either surrounded or not by the host membrane (Fig. 2C and 3A); whereas, degraded kleptoplasts were always surrounded 
by the host membrane with an electron-lucent space between the kleptoplast and the endoplasm of the host and showed inter-thylakoid spaces (Fig. 3B). In some cases, five membranes were visible around the chloroplast; the four inner membranes were most likely those of diatom chloroplast and the fifth and outermost membrane was that of the foraminifer (Fig. 3C and 3D). Foraminiferal mitochondria were abundant, well preserved with a double membrane and the presence of cristae in their matrix (Fig. 2C), confirming that the studied specimens were alive and healthy at the time of the fixation (Bernhard, 2000; Nomaki et al., 2016).

Two other organelles were found to be abundant: the lipid droplets and the residuals bodies. Lipid droplets were spherical, few of them were in a degradation state, and in some the opacity of the droplet was not uniform (i.e. brighter at the periphery than at the center, Fig. 3E and $3 \mathrm{~F}$ ). The residual bodies were also spherical and often filled with electron-dense circular particles (Fig. 3F and SI1).

Other foraminiferal organelles such as Golgi apparatus, fibrillar vesicles, endoplasmic reticulum (ER) and degradation vacuoles, were also observed in all chambers (Fig. 3E to F, Fig. SI1). Nuclei were observed in several specimens in the external whorl of E. williamsoni (Fig. 3G). The observed nuclei were spherical to partially lobate, with a size of $\sim 50 \mu \mathrm{m}$ and numerous nucleoli. At higher magnification, a lamina in contact with the inner membrane of the nuclear envelope and a double-membrane nuclear envelope with pores was observable (Fig. 3G-I). Most specimens were uninucleate, excepted two specimens with numerous small nuclei (size of $\sim 3 \mu \mathrm{m}$ ) in their cytoplasm (Fig. 3J, $\mathrm{n}^{*}$ ).

\section{Changes in ultrastructural features over the experiment}

The number of kleptoplasts was found to decrease significantly and gradually during the Light:Dark cycle experiment, from $6 \%$ of the total area of the cytoplasm to less than $3 \%$. But no differences were found between the kleptoplast abundances in the external and internal chambers studied (Fig. 4, Fig. 5 and Fig. 6). While, overall, most kleptoplasts kept their integrity (Fig. 4D and 4E), it seems that there were more degraded kleptoplasts after 15 days of incubations (Fig. 4F) as an increase of inter-thylakoid spaces was observed (Fig. 3B and 4F). The number of residual bodies also increased between days 0 and 9 , from 0.5 to $3 \%$ of the total area of the cytoplasm, and thereafter it stayed stable until the end of the experiment (Fig. 4, 6A and 6B). Moreover, similarly to the kleptoplasts, no differences were observed between the concentrations of residual bodies in the internal and external whorls (Fig. 5 and $6 B)$. 
The number of lipid droplets also increased over the experiment, from 2 to $6.7 \%$ of the total area of the cytoplasm. No lipid droplets were observed at the beginning of the experiment in some specimens; whereas they were abundant and homogeneously distributed in all specimens at the end (Fig. 4, 6A and 6B). Furthermore, and in contrast with kleptoplasts and residual bodies, the concentration of lipid droplets was higher in the internal than in the external whorl, 2.3 and $5.1 \%$, respectively. (Fig. 5 and 6B).

Over the Light:Dark cycle experiment, transmission electron micrographs also revealed that lipid droplets were often observed on the side of the kleptoplast (Fig. 7A to 7C). Furthermore, some lipid droplets accumulated in the area between the kleptoplast membranes and the membrane of the host (Fig. 7D to 7K). These lipids droplets are of similar shape and osmiophilicity as those seen in the cytoplasm of the host cell. It is worth mentioning that the interaction between smooth endoplasmic reticulum (SER) and lipid droplet usually observed in foraminiferal cells was also observed in the present experiment (Fig. SI 2), suggesting that both locations may be sites of lipid droplet biogenesis in kleptoplastidic foraminifera.

\section{Oxygen profiling and photosynthetic activity over the experiment}

The photosynthetic activity of E. williamsoni was constant over the first 9 days (Fig. 8). The dark respiration rates $(\mathrm{Rd})$ were between 2.21 and $2.95 \mathrm{nmolO}_{2}$ cell $\mathrm{d}^{-1} \mathrm{~d}^{-1}$, the maximum photosynthethic rates between 10.7 and $13.4 \mathrm{nmolO}_{2}$ cell $^{-1} \mathrm{~d}^{-1}$, the derived half saturation constants (Ek) were between 20 and $28 \mu \mathrm{mol}$ photons $\mathrm{m}^{-2} \mathrm{~s}^{-1}$, and Ic (compensation irradiance) values were low and similar over the first 9 days ( 4 to $8 \mu \mathrm{mol}$ photons $\mathrm{m}^{-2} \mathrm{~s}^{-1}$, Table 1). However, P-E curves (Fig. 8) and resulting parameters (Table 2) started to differ after 9 days of experiment. Rd and Ic significantly increased by a factor 2.5 and 3, respectively; whereas Ek decreased by a factor 4. Only alpha $(\alpha)$, the initial slope of the curve at a limiting irradiance and, interestingly, the maximum photosynthetic rates were not significantly modified over the Light/Dark cycle experiment. But, also not statistically significant, the last maximum photosynthetic rate, at day $15,\left(9.08 \pm 1.46 \mathrm{nmolO}_{2}\right.$ cell $\left.^{-1} \mathrm{~d}^{-1}\right)$ was lower than Pm values measured between days 0 and $9(10.7 \pm 1.91$ to $13.4 \pm 1.94$ $\mathrm{nmolO}_{2}$ cell $^{-1} \mathrm{~d}^{-1}$, Table 2). 


\section{Discussion}

In this study, we investigated the response of E. williamsoni to starvation, i.e. no addition of organic food source to experimental conditions. This species is known to be kleptoplastidic (Lopez, 1979, Jauffrais et al., 2018) and to have functional kleptoplasts that assimilate inorganic carbon (Lopez, 1979) and possibly inorganic nitrogen as it has been shown in Haynesina germanica (LeKieffre et al., 2018b), thus an autotrophic metabolism is possible.

Kleptoplast distributions within the endoplasm of E. williamsoni kept in the dark (Jauffrais et $a l ., 2018$ ) or exposed to Light:Dark cycle (present study) differed. In specimens kept in the dark, the kleptoplasts were mainly located close to the cell periphery in the external whorl (Jauffrais et al., 2018); whereas, in specimens exposed to Light:Dark cycle the kleptoplasts were more evenly distributed within the endoplasm. This difference of kleptoplasts organisation within the endoplasm of E. williamsoni supports the hypothesis that this species has the following behavioural strategy: it would be able to expose or protect its kleptoplasts to/from light by moving them into its cytoplasm as a function of the light intensity. Kleptoplast photo-damage might thus be avoided/reduced thanks to the host behavioural response to light, such as for kleptoplastidic sea slugs (Jesus et al., 2010, Cruz et al., 2015).

The kleptoplasts ultrastructural features -i.e. the pyrenoid, girdle lamella, thylakoids, the four membranes around the kleptoplasts, the absence of starch accumulation- and the molecular analyses show that E. williamsoni ingests mainly diatom kleptoplasts. Previous studies on coastal (Knight \& Mantoura, 1985, Goldstein et al., 2004, Pillet et al., 2011, Goldstein \& Richardson, 2018) and deep-sea kleptoplastidic foraminifera (Bernhard \& Bowser, 1999, Grzymski et al., 2002, Jauffrais et al., 2019) show the same preference for diatoms. A closer examination done using the $18 \mathrm{~S}$ rDNA sequences compared to diatom $18 \mathrm{~S}$ sequences available from GenBank indicates that all identified diatoms were mostly relatively large epipelic genera living in intertidal mudflats along the European Atlantic coast (Ribeiro et al., 2003, Meleder et al., 2007, Jesus et al., 2009). Most of the kleptoplasts present in E. williamsoni belonged to Nitzschia (13 sequences), Frustulia (3 sequences), Cocconeis (2 sequences) and Gyrosigma (2 sequences) as confirmed by the $18 \mathrm{~S}$ sequences. Considering the microphytobenthic abundance and composition in intertidal mudflats habitats along the European Atlantic coast (Ribeiro et al., 2003, Meleder et al., 2005, Jesus et al., 2009, Ribeiro et al., 2013), we can deduce that E. williamsoni selects and maintains kleptoplasts from large pennate diatoms. 
It is traditionally thought that kleptoplastidic organisms only sequester chloroplasts from their food source, i.e., no other algal organelles are theoretically retained (Clark et al., 1990). Nevertheless, diatom nuclear DNA was amplified in the present and other studies (Jauffrais et al., 2019), which supports the hypothesis that the diatom nucleus may be ingested, kept for some time (as the DNA can still be amplified) and then digested in kleptoplastidic foraminiferal species (within a few days?) as in other kleptoplastidic organisms (Green et al., 2000, Nagai et al., 2008, Hansen et al., 2016). Therefore, with continuous feeding on diatoms, the foraminiferal host might have enough diatom nucleus-encoded proteins preserved to maintain the cellular machinery necessary for kleptoplast maintenance, using nuclear DNA of freshly ingested diatoms.

Our results clearly show that $E$. williamsoni was capable of carrying out photosynthesis for at least 15 days under light/dark condition (Fig. 8). Similarly to $H$. germanica (Jauffrais et al., 2016), E. williamsoni has the ability to produce oxygen from low to relatively high irradiance. However, using the same setting as for H. germanica (Jauffrais et al., 2016) a lower compensation point (Ic) was found for E. williamsoni $\left(\sim 5 \mu \mathrm{mol}\right.$ photons $\left.\mathrm{m}^{-2} \mathrm{~s}^{-1}\right)$ than for $H$. germanica $\left(24 \mu \mathrm{mol}\right.$ photons $\left.\mathrm{m}^{-2} \mathrm{~s}^{-1}\right)$. We suggest that $E$. williamsoni is adapted to a lower light regime than $H$. germanica. Furthermore, no real photoinhibition was observed with the P(I) curves (Fig. 8) as a high onset of light saturation was found (> $600 \mu \mathrm{mol}$ photons $\mathrm{m}^{-2} \mathrm{~s}^{-1}$, Fig. 4). Consequently, E. williamsoni seems to be adapted to a broad range of light intensities such as the ones encountered in intertidal mudflat systems, close to $0 \mu \mathrm{mol}$ photons $\mathrm{m}^{-2} \mathrm{~s}^{-1}$ within the sediment or during high tide, to high intensity (> $1000 \mu \mathrm{mol}$ photons $\left.\mathrm{m}^{-2} \mathrm{~s}^{-1}\right)$ at the surface of the sediment during low tide. The maximum photosynthetic rates measured with $E$. williamsoni (10.7 to $13.4 \mathrm{nmolO}_{2}$ cell $^{-1} \mathrm{~d}^{-1}$, Table 1 ) were 10 times higher than with $H$. germanica (Jauffrais et al., 2016). It therefore confirms previous observations where $E$. williamsoni showed higher inorganic carbon uptake (5 times more) than $H$. germanica (Lopez, 1979).

The slow kleptoplast degradation observed on transmission electron micrographs (Fig. 4 and 6) seems to be correlated with the small decrease in Pm observed between day 9 and 15 . Similarly to what has been done with $H$. germanica using $F v / F m$ values (Jauffrais et al., 2016), a linear model was plotted to Pm values to estimate roughly the kleptoplast retention time. Under the present experimental conditions, the estimated kleptoplast retention time would be $\sim 70$ days. This time frame would qualify E. williamsoni as a long-term kleptoplast 
retention species (Clark et al., 1990) and this retention time is also much longer than for $H$. germanica, which has a retention time ranging from 7 to 21 days depending on light exposure.

The residual bodies are considered as autophagocytosis vacuoles (Leutenegger, 1977) or as vacuoles containing non-digestible remains (Hemleben et al., 1989). A recent overview of cellular ultrastructures in benthic foraminifera (LeKieffre et al., 2018a), established that it is extremely difficult to recognise any degraded organelle within residual bodies. The same authors suggest that the residual bodies are linked to metabolic pathways, as accumulation of isotopic labeled end-products derived from diatoms were observed in residual bodies of Ammonia sp. after two weeks of experiments (LeKieffre et al., 2017). In the present study, it was also difficult to link the accumulations of residual bodies to the degradation of specific organelles (Fig. SI 1). The observed specimens were starved, which hampered linking the accumulation of residual bodies with end-products derived from food assimilation but it supports the idea that they might be linked to autophagocytosis processes, i.e. vacuoles containing organelles recycling end-products. However, this process does not exclude that the increase in residual bodies could be linked to the observed decrease in kleptoplasts (Fig 6). The foraminifera would thus simply digest the kleptoplasts, and the increase in residual body would result from this digestion. Finally, the accumulation of residual bodies might also be associated with a stress triggered by the heterotrophic starvation, as it was observed in previous experiments exposing foraminifera to stressful conditions, such as a source of pollution (Morvan et al., 2004, Le Cadre \& Debenay, 2006).

The number of lipid droplets per cell in E. williamsoni was low at the beginning of the experiment, almost close to zero in some specimens. During the experiment, the number of lipid droplets increased. Moreover, this increase was accompanied by a decrease of the number of kleptoplasts and by their slow degradation (i.e. disorganisation of the thylakoid), an increase in the number of residual bodies, an increase in dark respiration $(\mathrm{Rd})$, and a minor decrease in photosynthetic rate $(\mathrm{Pm})$. Different hypotheses could explain these observations: (1) the thylakoid disorganisation could be due to the degradation of kleptoplast membrane lipids toward membrane lipid remodeling in lipid droplets (Siaut et al., 2011); (2) the increase of respiration rate and of the number of residual bodies may be explained by the degradation of carbohydrate reserves and the recycling of organelles to provide energy input for lipid synthesis; (3) despite the minor decrease in photosynthetic rates (Pm), the kleptoplast 
photosynthesis was still functional and used as a pathway for lipid synthesis (Goold et al., 2015, LeKieffre et al., 2018b).

TEM observations revealed similar lipid droplets compared to the ones already described in benthic foraminifera (reviewed in LeKieffre et al., 2018a). They are known as the primary carbon storage in foraminifera (Hottinger \& Dreher, 1974, Leutenegger, 1977, Hottinger, 1982, Pawlowski et al., 1995, LeKieffre et al., 2017). Similarly to residual bodies, the accumulation of lipid droplets in foraminifera is a known symptom of environmental stress, such as heavy metal toxicity and oil pollution (Morvan et al., 2004, Le Cadre \& Debenay, 2006, Frontalini et al., 2015, Frontalini et al., 2018). Our results show that starvation can be another factor triggering lipid droplet accumulation. The production of lipid droplets is also a common response of eukaryotes to environmental stress (e.g., starvation, salt, heavy metal toxicity) as it can be observed in diatoms and other microalgal species (Bérubé et al., 1999, Pandey et al., 2015, Jauffrais et al., 2016, Brembu et al., 2017).

In the conventional lipid biosynthetic pathway, widely accepted for most eukaryotic cells, lipids are assembled in the SER and stored in lipid droplets in the cytosol (Vertel et al., 1992). A close association of ER and lipid droplets was observed in E. williamsoni cytoplasm (Fig. SI 2), suggesting a similar pathway for lipid production in this foraminiferal species. However, an alternative cellular mechanism, involving the kleptoplasts, could also explain the lipid accumulation observed in E. williamsoni (Fig. 8). In some microalgal species, lipids are formed in chloroplasts and stored in that organelle and in the cytosol (Fan et al., 2011, Goodson et al., 2011, Simionato et al., 2013). The small lipid droplet accumulation observed between the kleptoplast and the host membranes (Fig. 8) supports the idea of a de novo lipid droplet synthesis pathway via the kleptoplasts in E. williamsoni. This was also observed in $H$. germanica (LeKieffre et al., 2018b) which suggests that this mechanism might be common, at least in some kleptoplastidic species. Based on this, newly formed E. williamsoni lipid droplets are probably partially synthesized de novo via ER and kleptoplasts, and partially originate from membrane lipid remodeling (i.e. the degradation of kleptoplast or other organelle membrane lipids to form lipid droplets). To confirm these hypotheses, an analysis of the intracellular fatty acids in this kleptoplastidic species is needed. Lipid synthesis requires an energy input, and under starvation (as it is the case in the present study), kleptoplastidic foraminifera could get the necessary energy input through kleptoplast photosynthesis. Finally, it cannot be ruled out that kleptoplasts might also be used as a carbon source stored in the foraminiferal cytoplasm to be slowly digested (within many days) during food impoverished periods. 
With due caution, if we accept that the organic carbon biosynthetic pathway partly involves kleptoplasts (Lopez, 1979, LeKieffre et al., 2018b), we suggest that, similarly to microalgae (Li et al., 2011, Jia et al., 2015), kleptoplasts from E. williamsoni might shift their carbon partitioning from carbohydrates into lipids as carbon and energy storage under stressful conditions.

\section{Conclusion}

In conclusion, our data shows that (i) E. williamsoni is capable of sustaining functional kleptoplasts for at least a 15-day period. (ii) Elphidium williamsoni is efficient at producing oxygen from low to relatively high irradiance, as shown by the low compensation point (Ic) of $\sim 5 \mu \mathrm{mol}$ photons $\mathrm{m}^{-2} \mathrm{~s}^{-1}$ and the high onset of light saturation. (iii) In kleptoplastidic foraminiferal species there might be a specificity for the species of diatom from which kleptoplasts are stolen. (iv). Our results suggest that $E$. williamsoni kleptoplasts might have an added value by providing extra carbon storage (carbohydrates and/or lipids synthesis). (v) Finally, although it requires further dedicated studies, the suggested ability of E. williamsoni to use different carbon partitioning for carbon storage illustrates the complex feeding strategies developed by kleptoplastidic foraminifera and opens questions regarding molecular mechanisms for carbon and energy storage depending on experimental and environmental conditions.

\section{Acknowledgments}

TJ was funded by the "FRESCO" project supported by the Region Pays de Loire and the University of Angers. This work was also supported by a grant from the French national program INSU/CNRS EC2CO-LEFE (project ForChlo). The authors thank the SCIAM imaging facility at the University of Angers (France) where the TEM and SEM images were produced with the help of Florence Manero and Romain Mallet, respectively.

We declare no conflict of interest.

\section{References}

Altschul SF, Madden TL, Schäffer AA, Zhang J, Zhang Z, Miller W \& Lipman DJ (1997) Gapped BLAST and PSI-BLAST: A new generation of protein database search programs. Nucleic Acids Res 25: 3389-3402.

Anisimova M \& Gascuel O (2006) Approximate likelihood-ratio test for branches: A fast, accurate, and powerful alternative. Syst Biol 55: 539-552.

Bernhard JM (2000) Distinguishing live from dead foraminifera: Methods review and proper applications. Micropaleontol 46: 38-46. 
Bernhard JM \& Bowser SS (1999) Benthic foraminifera of dysoxic sediments: chloroplast sequestration and functional morphology. Earth Sci Rev 46: 149-165.

Bérubé KA, Dodge JD \& Ford TW (1999) Effects of chronic salt stress on the ultrastructure of Dunaliella bioculata (Chlorophyta, Volvocales): Mechanisms of response and recovery. Eur J Phycol 34: 117-123.

Brembu T, Mühlroth A, Alipanah L \& Bones AM (2017) The effects of phosphorus limitation on carbon metabolism in diatoms. Philos Trans R Soc Lond B Biol Sci 372.

Cedhagen T (1991) Retention of chloroplasts and bathymetric distribution in the sublittoral foraminiferan Nonionellina labradorica. Ophelia 33: 17-30.

Cesbron F, Geslin E, LeKieffre C, Jauffrais T, Nardelli MP, Langlet D, Mabilleau G, Jorissen F, Jézéquel D \& Metzger E (2017) Sequestered chloroplasts in the benthic foraminifer Haynesina germanica: cellular organization, oxygen fluxes and potential ecological implications. J Foraminiferal Res 47: 268-278.

Clark KB, Jensen KR \& Stirts HM (1990) Survey for functional kleptoplasty among West Atlantic Ascoglossa (=Sacoglossa) (Mollusca: Opisthobranchia). Veliger 33: 339-345.

Correia MJ \& Lee JJ (2000) Chloroplast retention by Elphidium excavatum (Terquem). Is it a selective process? Symbiosis 29: 343-355.

Correia MJ \& Lee JJ (2002) Fine structure of the plastids retained by the foraminifer Elphidium excavatum (Terquem). Symbiosis 32: 15-26.

Correia MJ \& Lee JJ (2002) How long do the plastids retained by Elphidium excavatum (Terquem) last in their host? Symbiosis 32: 27-37.

Cruz S, Cartaxana P, Newcomer R, Dionísio G, Calado R, Serôdio J, Pelletreau KN \& Rumpho ME (2015) Photoprotection in sequestered plastids of sea slugs and respective algal sources. Sci Rep 5.

Darling KF, Schweizer M, Knudsen KL, et al. (2016) The genetic diversity, phylogeography and morphology of Elphidiidae (Foraminifera) in the Northeast Atlantic. Mar Micropaleontol 129: 1-23.

Edgar RC (2004) MUSCLE: Multiple sequence alignment with high accuracy and high throughput. Nucleic Acids Res 32: 1792-1797.

Edgar RC (2004) MUSCLE: A multiple sequence alignment method with reduced time and space complexity. BMC Bioinformatics 5: 1-19.

Fan J, Andre C \& Xu C (2011) A chloroplast pathway for the de novo biosynthesis of triacylglycerol in Chlamydomonas reinhardtii. FEBS Letters 585: 1985-1991. 
Frontalini F, Curzi D, Giordano FM, Bernhard JM, Falcieri E \& Coccioni R (2015) Effects of lead pollution on Ammonia parkinsoniana (foraminifera): Ultrastructural and microanalytical approaches. Eur J Histochem 59.

Frontalini F, Nardelli MP, Curzi D, Martín-González A, Sabbatini A, Negri A, Losada MT, Gobbi P, Coccioni R \& Bernhard JM (2018) Benthic foraminiferal ultrastructural alteration induced by heavy metals. Mar Micropaleontol 138: 83-89.

Fuller NJ, Tarran GA, Cummings DG, Woodward EMS, Orcutt KM, Yallop M, Le Gall F \& Scanlan DJ (2006) Molecular analysis of photosynthetic picoeukaryote community structure along an Arabian Sea transect. Limnol Oceanogr 51: 2502-2514.

Geslin E, Heinz P, Jorissen F \& Hemleben C (2004) Migratory responses of deep-sea benthic foraminifera to variable oxygen conditions: Laboratory investigations. Mar Micropaleontol 53: 227-243.

Geslin E, Risgaard-Petersen N, Lombard F, Metzger E, Langlet D \& Jorissen F (2011) Oxygen respiration rates of benthic foraminifera as measured with oxygen microsensors. J Exp Mar Biol Ecol 396: 108-114.

Goldstein ST \& Richardson EA (2018) Fine structure of the foraminifer Haynesina germanica (Ehrenberg) and its sequestered chloroplasts. Mar Micropaleontol 138: 6371.

Goldstein ST, Bernhard JM \& Richardson EA (2004) Chloroplast sequestration in the foraminifer Haynesina germanica: Application of high pressure freezing and freeze substitution. Microsc Microanal 10: 1458-1459.

Goodson C, Roth R, Wang ZT \& Goodenough U (2011) Structural correlates of cytoplasmic and chloroplast lipid body synthesis in Chlamydomonas reinhardtii and stimulation of lipid body production with acetate boost. Eukaryot Cell 10: 1592-1606.

Goold H, Beisson F, Peltier G \& Li-Beisson Y (2015) Microalgal lipid droplets: composition, diversity, biogenesis and functions. Plant Cell Rep 34: 545-555.

Gouy M, Guindon S \& Gascuel O (2010) Sea view version 4: A multiplatform graphical user interface for sequence alignment and phylogenetic tree building. Mol Biol Evol 27: 221224.

Green BJ, Li WY, Manhart JR, Fox TC, Summer EJ, Kennedy RA, Pierce SK \& Rumpho ME (2000) Mollusc-algal chloroplast endosymbiosis. Photosynthesis, thylakoid protein maintenance, and chloroplast gene expression continue for many months in the absence of the algal nucleus. Plant Physiol 124: 331-342. 
Grzymski J, Schofield OM, Falkowski PG \& Bernhard JM (2002) The function of plastids in the deep-sea benthic foraminifer, Nonionella stella. Limnol Oceanogr 47: 1569-1580.

Guindon S \& Gascuel O (2003) A simple, fast, and accurate algorithm to estimate large phylogenies by maximum likelihood. Syst Biol 52: 696-704.

Hansen PJ, Ojamäe K, Berge T, Trampe EC, Nielsen LT, Lips I \& Kühl M (2016) Photoregulation in a kleptochloroplastidic dinoflagellate, Dinophysis acuta. Frontiers Microbiol 7.

Heinz P, Geslin E \& Hemleben C (2005) Laboratory observations of benthic foraminiferal cysts. Mar Biol Res 1: 149-159.

Hemleben C, Spindler M \& Anderson OR (1989) Modern Planktonic Foraminifera.

Høgslund S, Revsbech NP, Cedhagen T, Nielsen LP \& Gallardo VA (2008) Denitrification, nitrate turnover, and aerobic respiration by benthic foraminiferans in the oxygen minimum zone off Chile. J Exp Mar Biol Ecol 359: 85-91.

Hottinger L (1982) Larger foraminifera, giant cells with a historical background. Naturwissenschaften 69: 361-371.

Hottinger L \& Dreher D (1974) Differentiation of protoplasm in nummulitidae (Foraminifera) from Elat, Red Sea. Mar Biol 25: 41-61.

Jauffrais T, Jesus B, Méléder V \& Geslin E (2017) Functional xanthophyll cycle and pigment content of a kleptoplastic benthic foraminifer: Haynesina germanica. PLOS ONE 12: $\mathrm{e} 0172678$.

Jauffrais T, Jesus B, Geslin E, Briand F \& Martin-Jézéquel V (2016) Locomotion speed of the benthic foraminifer Ammonia tepida exposed to different nitrogen and carbon sources. $J$ Sea Res 118: 52-58.

Jauffrais T, Jesus B, Metzger E, Mouget JL, Jorissen F \& Geslin E (2016) Effect of light on photosynthetic efficiency of sequestered chloroplasts in intertidal benthic foraminifera (Haynesina germanica and Ammonia tepida). Biogeosciences 13: 2715-2726.

Jauffrais T, Jesus B, Méléder V, Turpin V, Russo ADAPG, Raimbault P \& Martin-Jézéquel V (2016) Physiological and photophysiological responses of the benthic diatom Entomoneis paludosa (Bacillariophyceae) to dissolved inorganic and organic nitrogen in culture. Mar Biol 163: 1-14.

Jauffrais T, LeKieffre C, Koho KA, Tsuchiya M, Schweizer M, Bernhard JM, Meibom A \& Geslin E (2018) Ultrastructure and distribution of kleptoplasts in benthic foraminifera from shallow-water (photic) habitats. Mar Micropaleontol 46-62. 
Jauffrais T, LeKieffre C, Schweizer M, Geslin E, Metzger E, Bernhard JM, Jesus B, Filipsson HL, Maire O \& Meibom A (2019) Kleptoplastidic benthic foraminifera from aphotic habitats: insights into assimilation of inorganic $\mathrm{C}, \mathrm{N}$ and $\mathrm{S}$ studied with sub-cellular resolution. Environ Microbiol 21: 125-141.

Jesus B, Ventura P \& Calado G (2010) Behaviour and a functional xanthophyll cycle enhance photo-regulation mechanisms in the solar-powered sea slug Elysia timida (Risso, 1818). J Exp Mar Biol Ecol 395: 98-105.

Jesus B, Perkins RG, Consalvey M, Brotas V \& Paterson DM (2006) Effects of vertical migrations by benthic microalgae on fluorescence measurements of photophysiology. Mar Ecol Prog Ser 315: 55-66.

Jesus B, Brotas V, Ribeiro L, Mendes CR, Cartaxana P \& Paterson DM (2009) Adaptations of microphytobenthos assemblages to sediment type and tidal position. Cont Shelf Res 29: 1624-1634.

Jia J, Han D, Gerken HG, Li Y, Sommerfeld M, Hu Q \& Xu J (2015) Molecular mechanisms for photosynthetic carbon partitioning into storage neutral lipids in Nannochloropsis oceanica under nitrogen-depletion conditions. Algal Research 7: 66-77.

Knight R \& Mantoura RFC (1985) Chlorophyll and carotenoid pigments in foraminifera and their symbiotic algae: analysis by high performance liquid chromatography Mar Ecol Prog Ser 23: 241-249.

Le Cadre V \& Debenay JP (2006) Morphological and cytological responses of Ammonia (foraminifera) to copper contamination: Implication for the use of foraminifera as bioindicators of pollution. Environ Pollut 143: 304-317.

Lee JJ, Lanners E \& Ter Kuile B (1988) The retention of chloroplasts by the foraminifera Elphidium crispum. Symbiosis 5: 45-60.

LeKieffre C, Spangenberg JE, Mabilleau G, Escrig S, Meibom A \& Geslin E (2017) Surviving anoxia in marine sediments: The metabolic response of ubiquitous benthic foraminifera (Ammonia tepida). PLOS ONE 12: e0177604.

LeKieffre C, Bernhard JM, Mabilleau G, Filipsson HL, Meibom A \& Geslin E (2018) An overview of cellular ultrastructure in benthic foraminifera: New observations of rotalid species in the context of existing literature. Mar Micropal 138: 12-32.

LeKieffre C, Jauffrais T, Geslin E, Jesus B, Bernhard JM, Giovani ME \& Meibom A (2018) Inorganic carbon and nitrogen assimilation in cellular compartments of a benthic kleptoplastic foraminifer. Sci Rep 8. 
Leutenegger S (1977) Ultrastructure de foraminifères perforés et imperforés ainsi que de leurs symbiotes. Cahiers de Micropal 3: 1-161.

Li YH \& Gregory S (1974) Diffusion of ions in sea-water and deep-sea sediments. Geochim Cosmochim Acta 38: 703-714.

Li YT, Han DX, Sommerfeld M \& Hu QA (2011) Photosynthetic carbon partitioning and lipid production in the oleaginous microalga Pseudochlorococcum sp (Chlorophyceae) under nitrogen-limited conditions. Bioresour Technol 102: 123-129.

Lopez E (1979) Algal chloroplasts in the protoplasm of three species of benthic foraminifera: taxonomic affinity, viability and persistence. Mar Biol 53: 201-211.

Meleder V, Rince Y, Barille L, Gaudin P \& Rosa P (2007) Spatiotemporal changes in microphytobenthos assemblages in a macrotidal flat (Bourgneuf bay, France). J Phycol 43: $1177-1190$.

Meleder V, Barille L, Rince Y, Morancais M, Rosa P \& Gaudin P (2005) Spatio-temporal changes in microphytobenthos structure analysed by pigment composition in a macrotidal flat (Bourgneuf Bay, France). Mar Ecol Prog Ser 297: 83-99.

Moodley L, Van Der Zwaan GJ, Rutten GMW, Boom RCE \& Kempers AJ (1998) Subsurface activity of benthic foraminifera in relation to porewater oxygen content: Laboratory experiments. Mar Micropaleontol 34: 91-106.

Morvan J, Le Cadre V, Jorissen F \& Debenay JP (2004) Foraminifera as potential bioindicators of the "Erika" oil spill in the Bay of Bourgneuf: Field and experimental studies. Aquat Living Resour 17: 317-322.

Mouget JL, Perkins R, Consalvey M \& Lefebvre S (2008) Migration or photoacclimation to prevent high irradiance and UV-B damage in marine microphytobenthic communities. Aqua Microbial Ecol 52: 223-232.

Müller P, Li X-P \& Niyogi KK (2001) Non-Photochemical Quenching. A response to excess light energy. Plant Physiol 125: 1558-1566.

Nagai S, Nitshitani G, Tomaru Y, Sakiyama S \& Kamiyama T (2008) Predation by the toxic dinoflagellate Dinophysis fortii on the ciliate Myrionecta rubra and observation of sequestration of ciliate chloroplasts. J Phycol 44: 909-922.

Nomaki H, Bernhard JM, Ishida A, Tsuchiya M, Uematsu K, Tame A, Kitahashi T, Takahata N, Sano Y \& Toyofuku T (2016) Intracellular isotope localization in Ammonia sp. (Foraminifera) of oxygen-depleted environments: Results of nitrate and sulfate labeling experiments. Frontiers Microbiol 7: 1-12. 
Pandey LK, Han T \& Gaur JP (2015) Response of a phytoplanktonic assemblage to copper and zinc enrichment in microcosm. Ecotoxicol 24: 573-582.

Pawlowski J (2000) Introduction to the molecular systematics of foraminifera. Micropaleontol 46: $1-12$.

Pawlowski J, Swiderski Z \& Lee JJ (1995) Observations on the ultrastructure and reproduction of Trochammina sp. (Foraminiferida). Proceedings of the Fourth International Workshop on Agglutinated Foraminifera 233-237.

Perkins RG, Lavaud J, Serodio J, Mouget JL, Cartaxana P, Rosa P, Barille L, Brotas V \& Jesus BM (2010) Vertical cell movement is a primary response of intertidal benthic biofilms to increasing light dose. Mar Ecol Prog Ser 416: 93-103.

Pillet L, de Vargas C \& Pawlowski J (2011) Molecular identification of sequestered diatom chloroplasts and kleptoplastidy in foraminifera. Protist 162: 394-404.

Platt T, Gallegos CL \& Harrison WG (1980) Photoinhibition of photosynthesis in natural assemblages of marine phytoplancton J Mar Res 38: 687-701.

Ribeiro L, Brotas V, Mascarell G \& Coute A (2003) Taxonomic survey of the microphytobenthic communities of two Tagus estuary mudflats. Acta Oecol-Int J Ecol 24: S117-S123.

Ribeiro L, Brotas V, Rince Y \& Jesus B (2013) Structure and diversity of intertidal benthic diatom assemblages in contrasting shores: A case study from the Tagus estuary. $J$ Phycol 49: 258-270.

Roberts A, Austin W, Evans K, Bird C, Schweizer M \& Darling K (2016) A new integrated approach to taxonomy: The fusion of molecular and morphological systematics with type material in benthic foraminifera. PLoS ONE 11: doi:10.1371/journal.pone.0158754.

Schneider CA, Rasband WS \& Eliceiri KW (2012) NIH Image to ImageJ: 25 years of image analysis. Nat Meth 9: 671-675.

Schweizer M, Pawlowski J, Duijnstee IAP, Kouwenhoven TJ \& Van Der Zwaan GJ (2005) Molecular phylogeny of the foraminiferal genus Uvigerina based on ribosomal DNA sequences. Mar Micropaleontol 57: 51-67.

Siaut M, Cuiné S, Cagnon C, et al. (2011) Oil accumulation in the model green alga Chlamydomonas reinhardtii: Characterization, variability between common laboratory strains and relationship with starch reserves. BMC Biotechnol 11.

Simionato D, Block MA, La Rocca N, Jouhet J, Maréchal E, Finazzi G \& Morosinotto T (2013) The response of Nannochloropsis gaditana to nitrogen starvation includes de 
novo biosynthesis of triacylglycerols, a decrease of chloroplast galactolipids, and reorganization of the photosynthetic apparatus. Eukaryot Cell 12: 665-676.

Tavaré S (1986) Some probabilistic and statistical problems in the analysis of DNA sequences. Lectures on Mathematics in the Life Sciences, Vol. 17 (Miura RM, ed.) p.^pp. 57-86. Am. Math. Soc., Providence.

Tsuchiya M, Toyofuku T, Uematsu K, Brüchert V, Collen J, Yamamoto H \& Kitazato H (2015) Cytologic and genetic characteristics of endobiotic bacteria and kleptoplasts of Virgulinella fragilis (Foraminifera). J Euk Microbiol 62: 454-469.

Vertel BM, Walters LM \& Mills D (1992) Subcompartments of the endoplasmic reticulum. Sem Cell Biol 3: 325-341.

West NJ, Schönhuber WA, Fuller NJ, Amann RI, Rippka R, Post AF \& Scanlan DJ (2001) Closely related Prochlorococcus genotypes show remarkably different depth distributions in two oceanic regions as revealed by in situ hybridization using $16 \mathrm{~S}$ rRNA-targeted oligonucleotides. Microbiol 147: 1731-1744. 


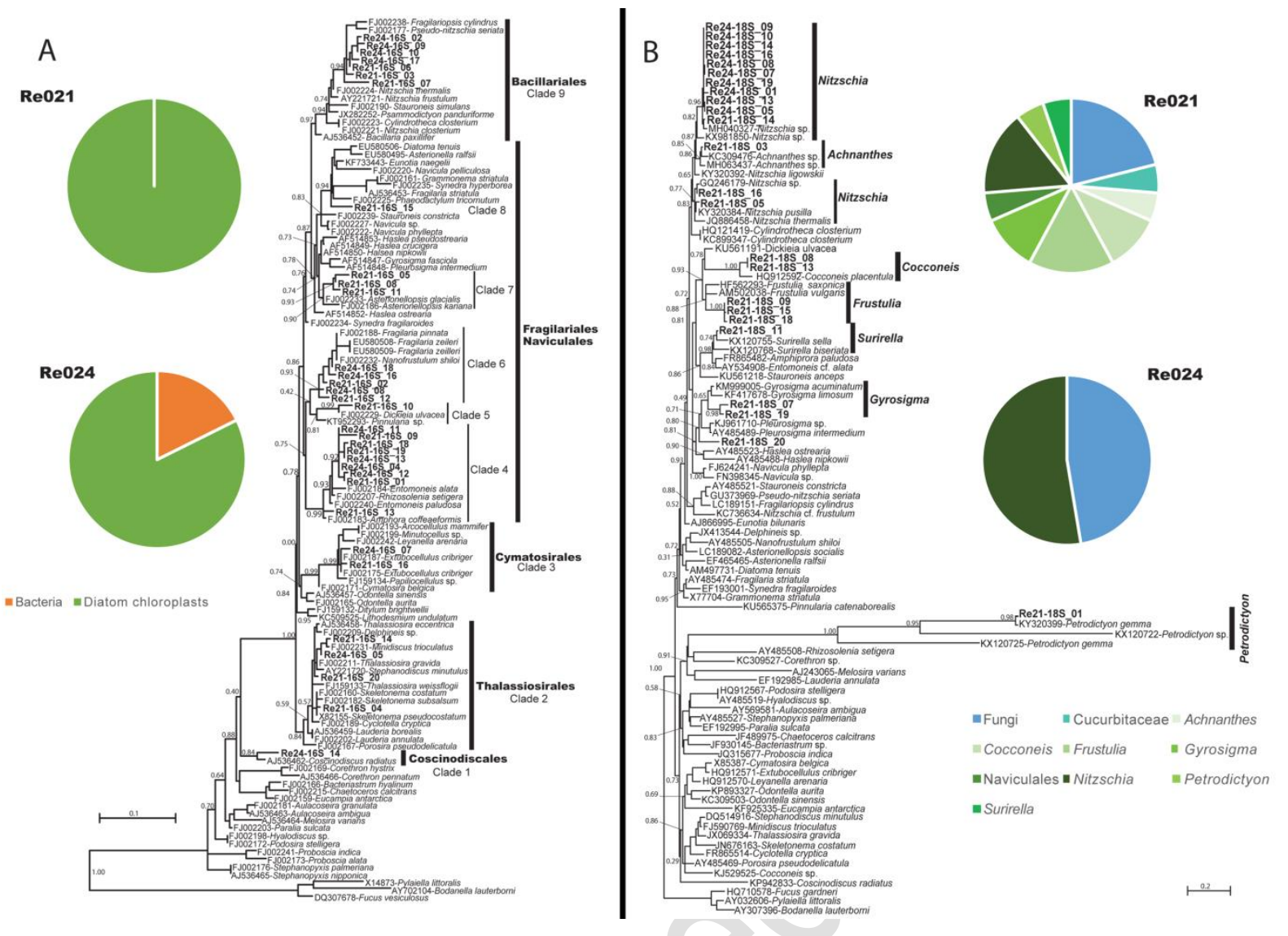

Figure 1. Pie charts showing percentage distributions of taxonomic groups sequenced in two specimens of E. williamsoni Re021 and Re024 and phylogenetic trees (ML+G model) for $16 \mathrm{~S}(\mathrm{~A})$ and $18 \mathrm{~S}(\mathrm{~B})$ sequences.
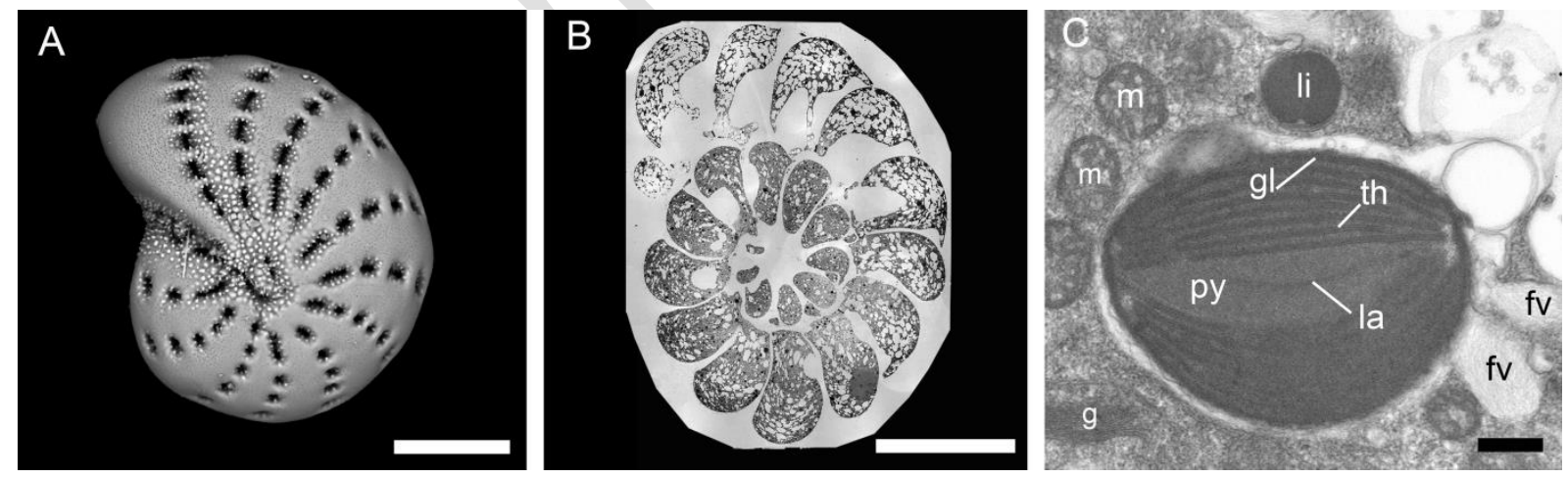

Figure 2. Elphidium williamsoni (elphidiid phylotype S1, Darling et al. 2016), control specimen (not exposed to light) isolated from Isle of Ré (France) intertidal sediments. A. Scanning electron micrograph. B. Transmission electron micrograph, overview of different chambers of $E$. williamsoni. C. Transmission electron micrographs, overview of a kleptoplast and surrounding organelles. $\mathrm{m}$ : mitochondria, li: lipid droplets, gl: girdle lamella, th: thylakoid, py: pyrenoid with a lamella (la), fv: fibrillar vesicles, g: Golgi apparatus. Scale bars: $A-B=50 \mu \mathrm{m}, C=0.5 \mu \mathrm{m}$. 

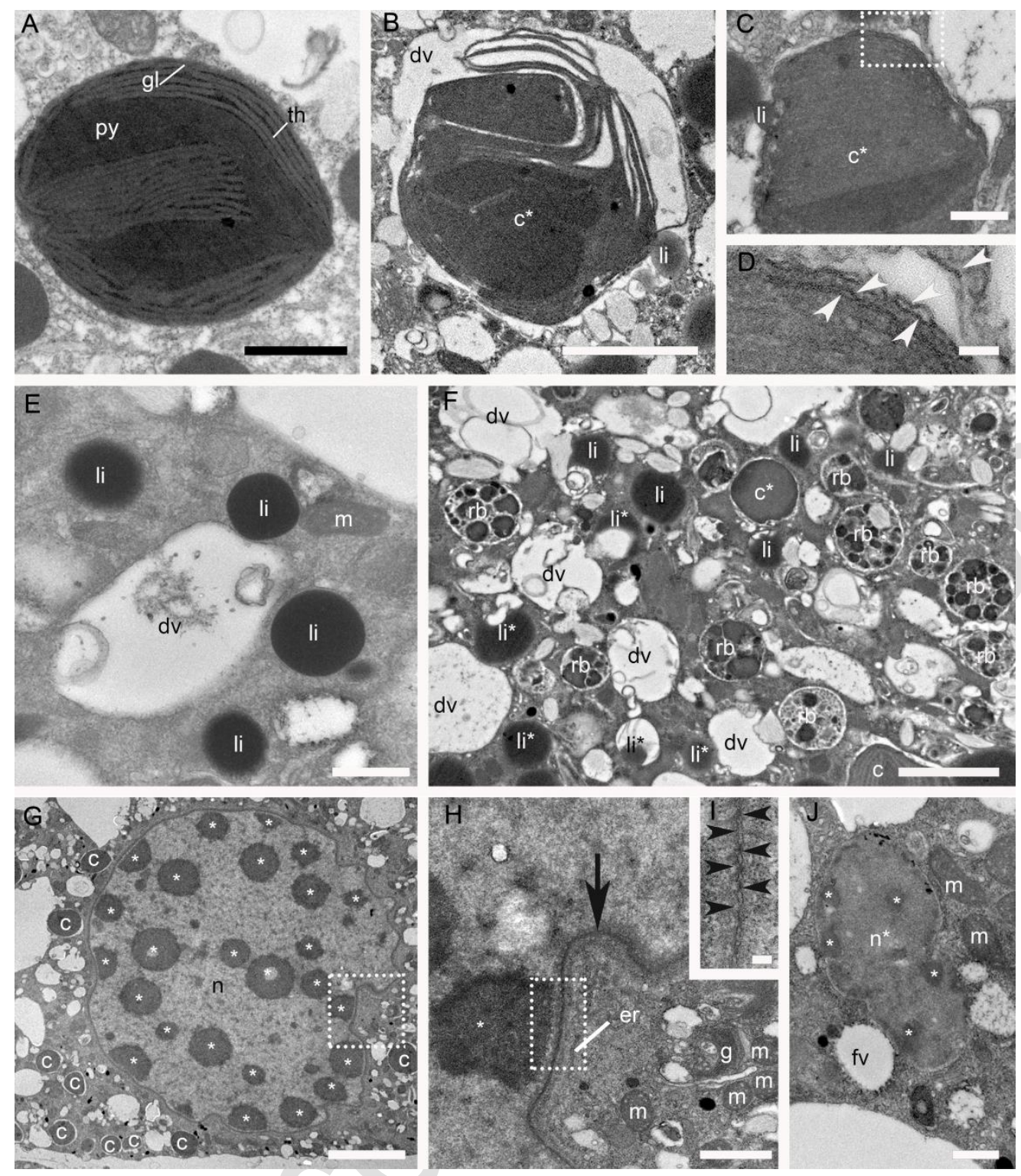

Figure 3. Transmission electron micrographs of some organelles of Elphidium williamsoni. A. Healthy kleptoplast. B. Degraded kleptoplast. C. Overview of a kleptoplast in degradation. D. High magnification micrograph of the same kleptoplast in degradation, showing the four membranes typical of a diatom chloroplast and a $5^{\text {th }}$ one from the host (white arrowheads) which surround the kleptoplast. E. Lipid droplets (li) well defined and less opaque dense at the periphery in the cytoplasm. F. Residual bodies (rd), digestive vacuoles (dv) and lipid droplets (li) in the cytoplasm of $E$. williamsoni. G. Overview of a nucleus with numerous nucleoli $(*)$. H-I. Higher magnification of a nucleus showing a peripheral nucleolus, the double nuclear envelope (black arrow) with some pores (I, black arrowheads) and surrounding organelles (endoplasmic reticulum, mitochondria, Golgi apparatus). J. Some specimens of $E$. williamsoni were found to have multiple nuclei, a large nucleus (G) and numerous small nuclei $\left(\mathrm{J}, \mathrm{n}^{*}\right)$ with also numerous nucleoli $\left({ }^{*}\right)$. gl: girdle lamella, th: thylakoid, py: pyrenoid, c: kleptoplasts, $c^{*}$ : kleptoplasts in degradation, li: lipid droplets, li*: lipid droplets in degradation, $\mathrm{rb}$ : residual bodies, $\mathrm{n}$ : nucleus, ${ }^{*}$ : nucleolus, $\mathrm{m}$ : mitochondria, er: endoplasmic reticulum, g: Golgi apparatus, dv: digestive vacuoles, fv: fibrillar vesicles,. Scale bars: $A-B=2 \mu \mathrm{m}, C=$ $0.5 \mu \mathrm{m}, \mathrm{D}=50 \mathrm{~nm}, \mathrm{E}=1 \mu \mathrm{m}, \mathrm{F}=2 \mu \mathrm{m}, \mathrm{G}=5 \mu \mathrm{m}, \mathrm{H}=1 \mu \mathrm{m}, \mathrm{I}=100 \mathrm{~nm}, \mathrm{~J}=0.5 \mu \mathrm{m}$. 

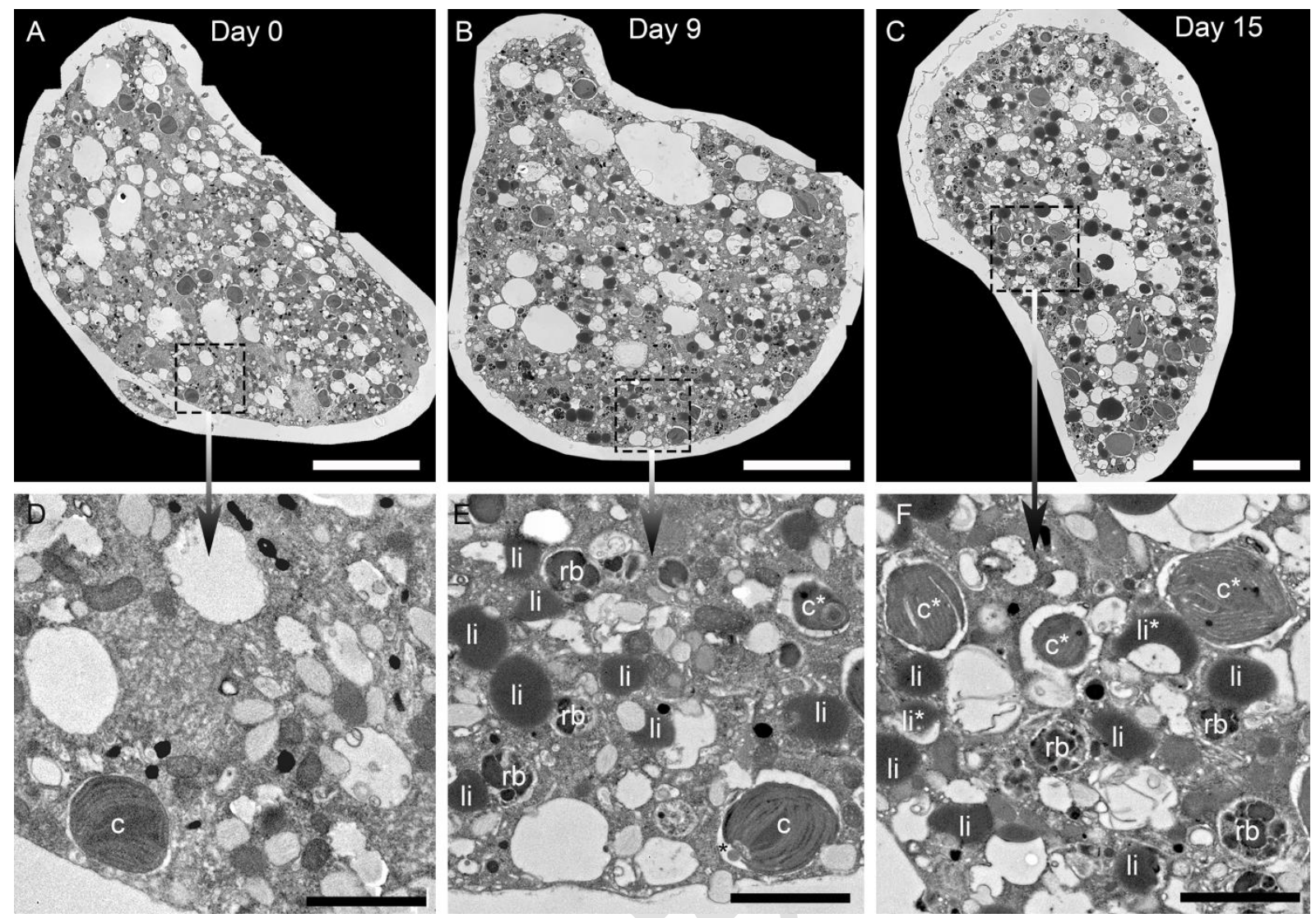

Figure 4. Transmission electron micrographs at low (A-C) and high magnification (D-F) of a chamber situated in the internal whorl ( $n-12$ to $n-17)$ of Elphidium williamsoni at Day 0 ( $A$ and $D$ ) Day 9 ( $B$ and $\mathrm{E})$ and Day 15 ( $\mathrm{C}$ and F) of the Light:Dark cycle experiment. A focus was done on the ultrastructural organisation and amount of three specific organelles: the healthy $(c)$ and degraded kleptoplasts $\left(c^{*}\right)$, the healthy (li) and degraded lipid droplets (li*) and the residual bodies (rb). Scale bars: $A-C=10 \mu \mathrm{m}$, $\mathrm{D}-\mathrm{F}=2 \mu \mathrm{m}$. 

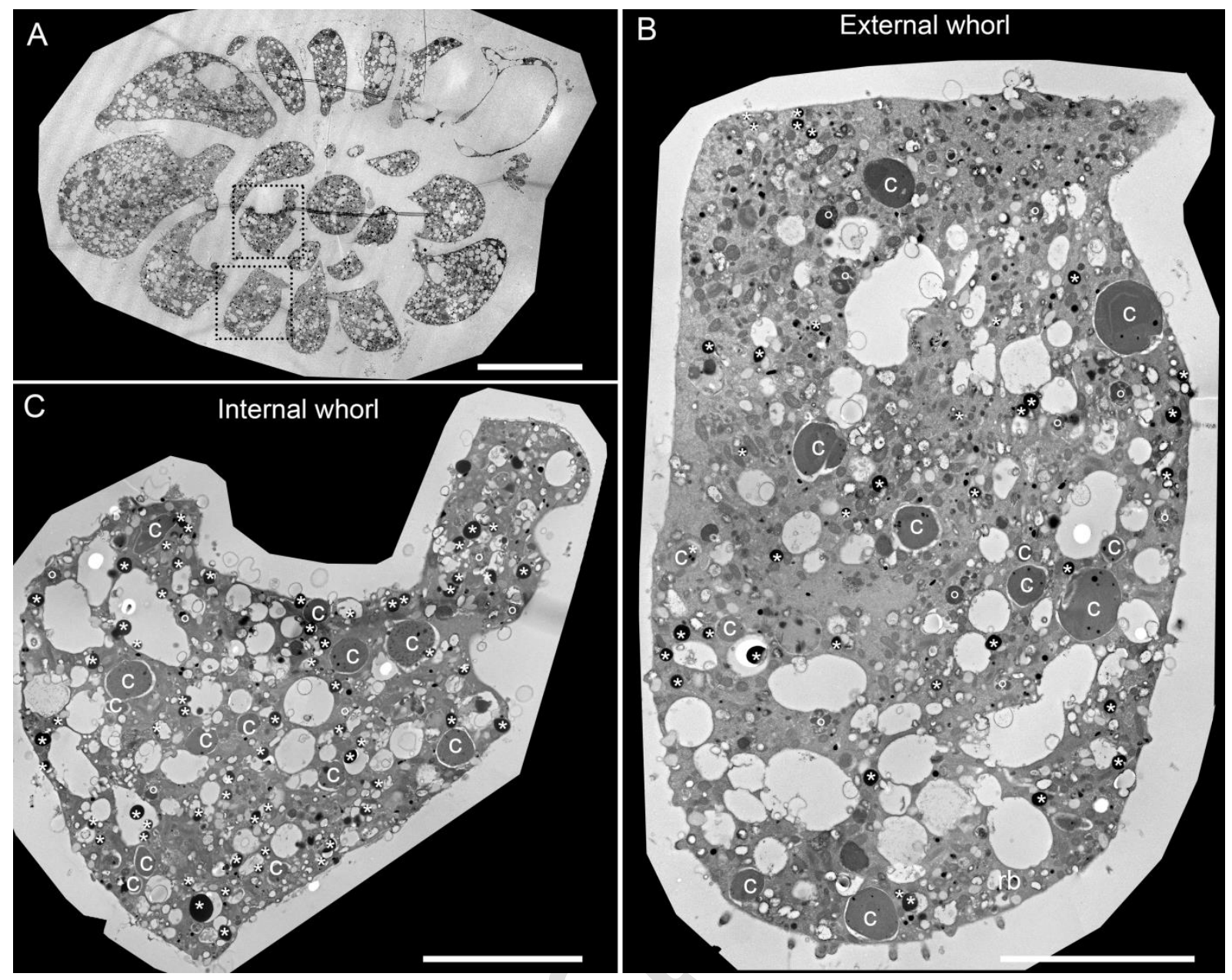

Figure 5. Transmission electron micrographs of Elphidium williamsoni (A) showing the ultrastructural organization of an external (B) and an internal chamber (C). A focus was done on the ultrastructural organisation and amount of three specific organelles: the kleptoplasts (c), the lipid droplets $\left(^{*}\right)$ and the residual bodies $\left({ }^{\circ}\right)$. Scale bars: $A=50 \mu \mathrm{m}, \mathrm{B}-\mathrm{C}=10 \mu \mathrm{m}$. 

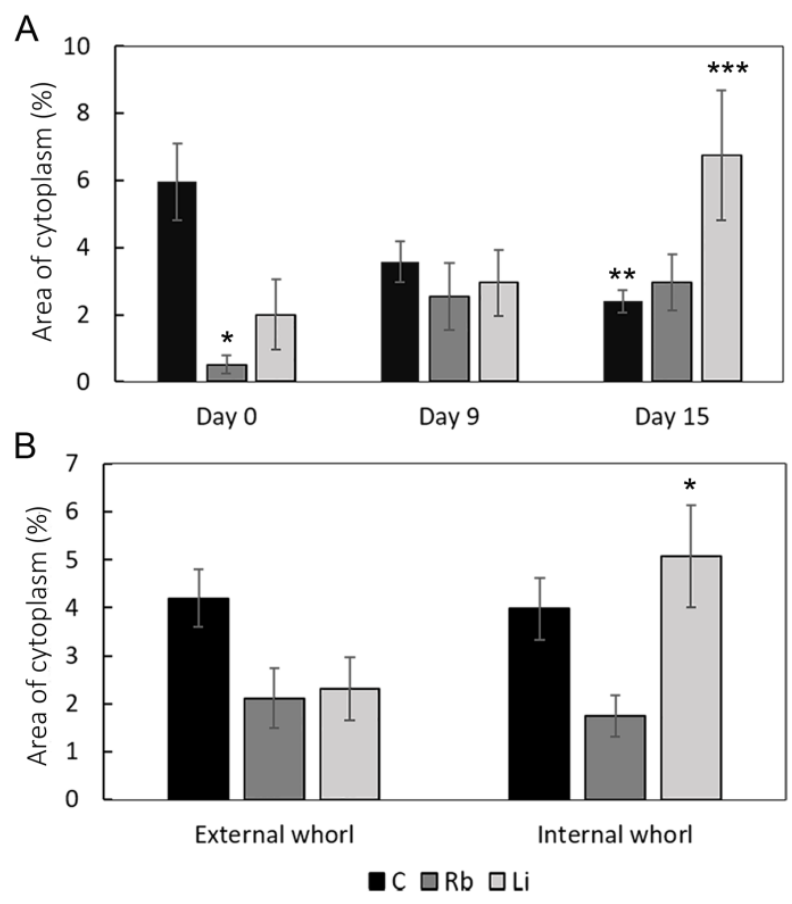

Figure 6. Area of cytoplasm per chamber (\%, A and B) occupied by kleptoplasts (C), residual bodies $(\mathrm{Rb})$ and lipid droplets (Li) over the experiment (Day 0, 9 and 15) and between chambers from either the external or the internal foraminiferal whorl $(n=5$ and error bars $=S D) . *, * *, * * *$ Denotes a statistically significant difference with $95 \%$ confidence level using a LSD analysis. 

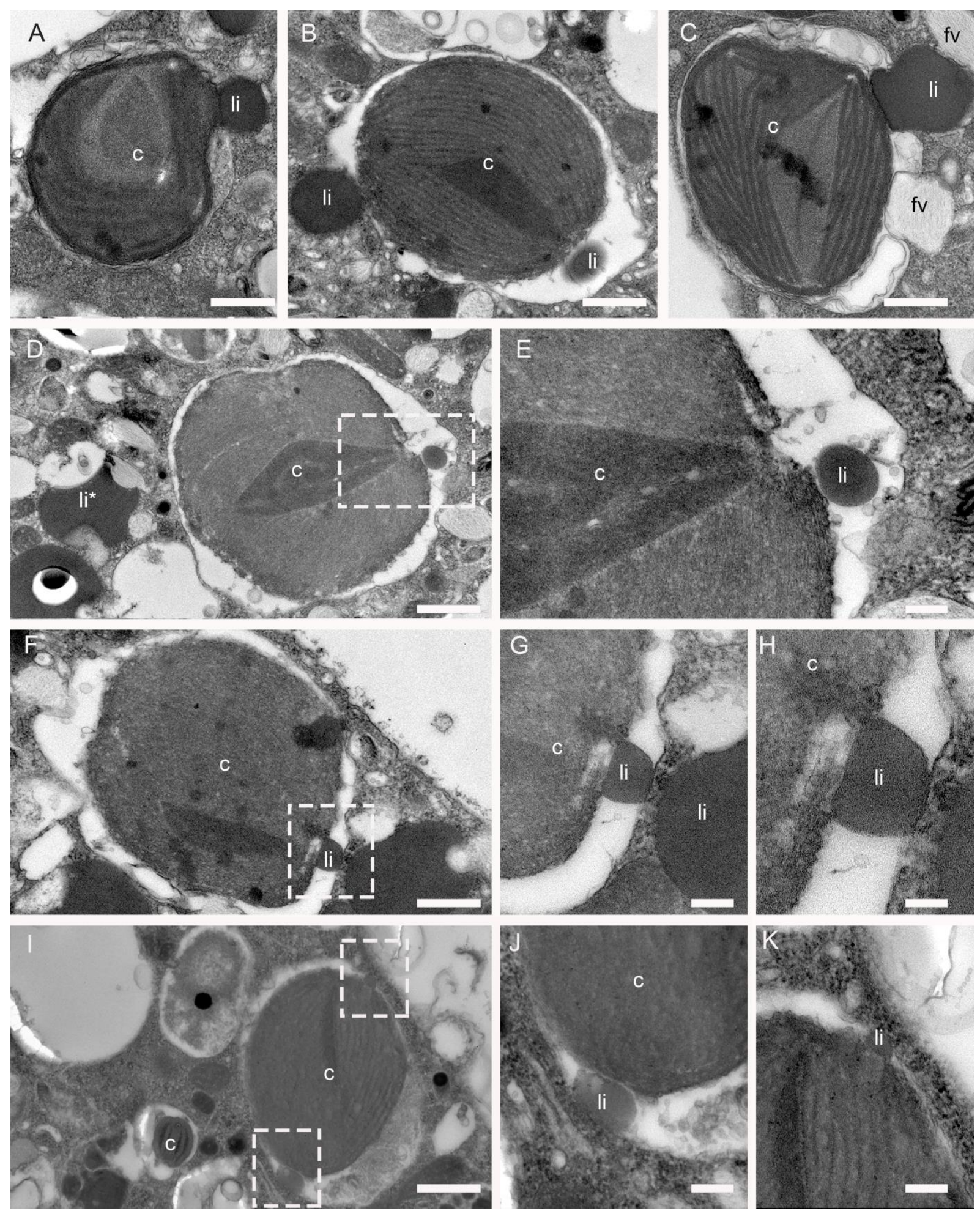

Figure 7. Transmission electron micrographs at low and high magnification of kleptoplasts and lipid droplets. A-K. Accumulation of lipid droplets in the space between the kleptoplast membrane and the vacuole membrane. c: kleptoplasts, li: lipid droplets, li*: lipid droplets in degradation. Scale bars: $A-D=0.5 \mu \mathrm{m}, E=100 \mathrm{~nm}, \mathrm{~F}=0.5 \mu \mathrm{m}, \mathrm{G}=100 \mathrm{~nm}, \mathrm{H}=50 \mathrm{~nm}, \mathrm{I}=0.5 \mu \mathrm{m}, \mathrm{J}-\mathrm{K}=100 \mathrm{~nm}$. 


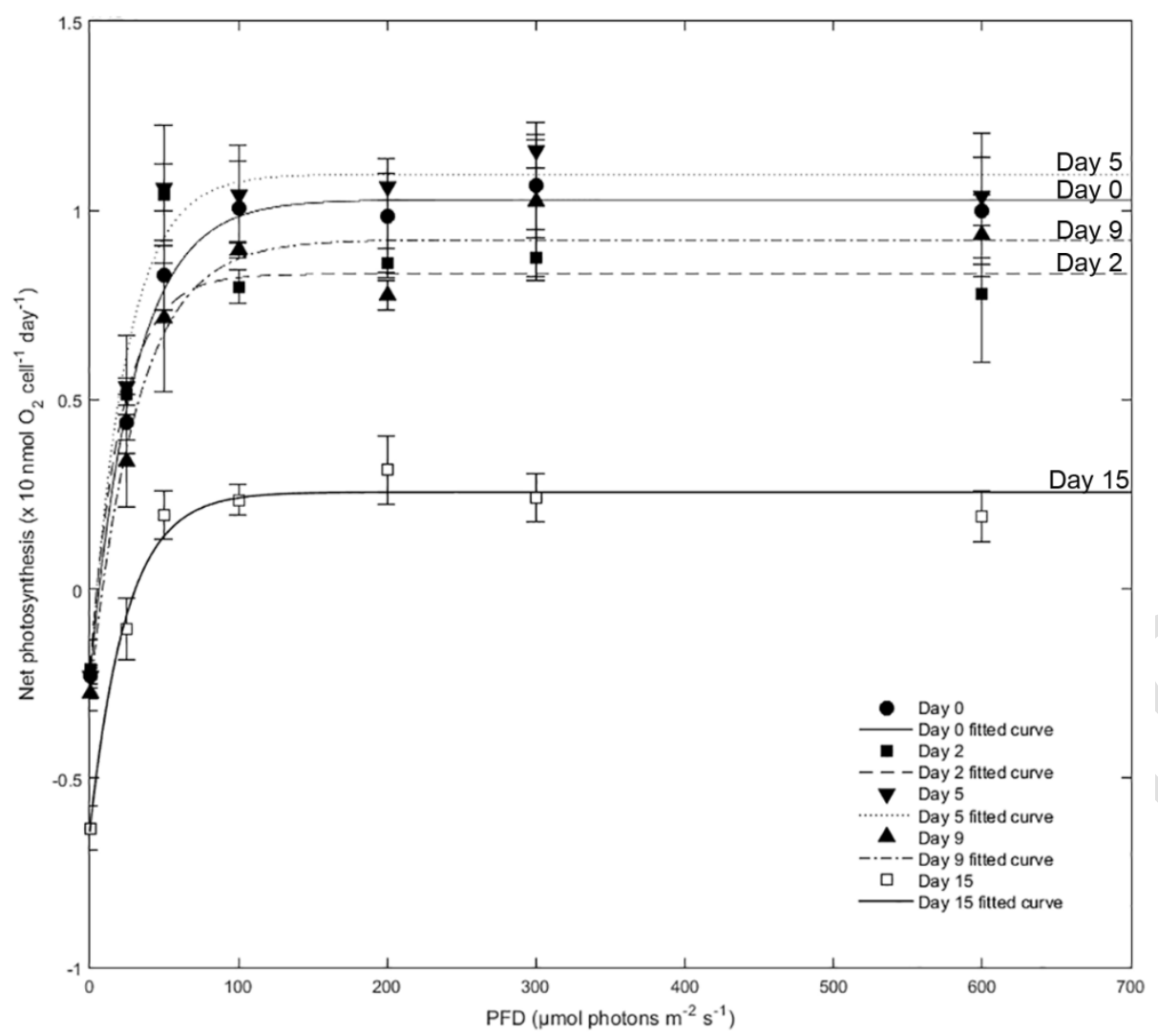

Figure 8. Net photosynthesis of Elphidium williamsoni $\left(\times 10 \mathrm{nmolO}_{2}\right.$ cell $\left.^{-1} \mathrm{~d}^{-1}\right)$ as a function of the photon flux density (PFD, $\mu \mathrm{mol}$ photons $\mathrm{m}^{-2} \mathrm{~s}^{-1}$ ) fitted with the model Platt et al (1980). ( $\mathrm{N}=3$, error bars = SD). 
Table 1. . GenBank accession numbers for new sequences deposited with this study for each foraminifer individual (Re021 and Re024) with the different primers used.

\begin{tabular}{|l|l|l|l|}
\hline DNA isolate & S14F1-N6 & PLA491F-OXY1313R & DiatSSUF-DiatSSUR \\
\hline Re021 & MH523444 & MH522718-MH522736 & MH532905-MH532923 \\
\hline Re024 & MH523445 & MH522737-MH522753 & MH532924-MH532942 \\
\hline
\end{tabular}

Table 2. Parameters estimated from photosynthetic activity of $E$. williamsoni using the model of Platt et al. (1980). Where $\mathrm{Rd}$ is the dark respiration rate $\left(\mathrm{nmolO}_{2}\right.$ cell $\left.^{-1} \mathrm{~d}^{-1}\right), \mathrm{Pm}$ is the maximum photosynthetic rate $\left(n \mathrm{nolO}_{2}\right.$ cell $\left.^{-1} \mathrm{~d}^{-1}\right)$, and alpha $(\alpha)$ the initial slope of the $P(I)$ curve at limiting irradiance. The half-saturation constant Ek and the compensation irradiance Ic ( $\mu \mathrm{mol}$ photons $\mathrm{m}^{-2} \mathrm{~s}^{-1}$ ) were calculated according to Eqs. (2) and (3). Data are expressed as mean \pm standard deviation (SD).

\begin{tabular}{|c|c|c|c|c|c|}
\hline & $\begin{array}{c}R d \\
\mathrm{nmolO}_{2} \text { cell }^{-1} d^{-1}\end{array}$ & $\begin{array}{c}\mathrm{Pm} \\
\mathrm{nmolO}_{2} \text { cell }^{-1} \mathrm{~d}^{-1}\end{array}$ & alpha & $\begin{array}{c}\text { IC } \\
\mu \mathrm{mol} \text { photons } \mathrm{m}^{-2} \mathrm{~s}^{-1}\end{array}$ & $\begin{array}{c}\text { Ek } \\
\mu \mathrm{mol} \text { photons } \mathrm{m}^{-2} \mathrm{~s}^{-1}\end{array}$ \\
\hline Day 0 & $2.42 \pm 0.5$ & $12.75 \pm 2.82$ & $448 \pm 60$ & $5.6 \pm 1.8$ & $23.8 \pm 8.2$ \\
\hline Day 2 & $2.21 \pm 1.27$ & $10.70 \pm 1.91$ & $318 \pm 96$ & $7.8 \pm 6.0$ & $27.9 \pm 7.1$ \\
\hline Day 5 & $2.45 \pm 0.41$ & $13.41 \pm 1.94$ & $568 \pm 55$ & $4.4 \pm 0.9$ & $19.5 \pm 3.3$ \\
\hline Day 9 & $2.95 \pm 0.64$ & $12.18 \pm 1.96$ & $418 \pm 193$ & $7.8 \pm 2.5$ & $25.1 \pm 10.7$ \\
\hline Day 15 & $6.42 \pm 0.95^{\star \star}$ & $9.08 \pm 1.46$ & $390 \pm 189$ & $18.7 \pm 7.2^{\star \star}$ & $7.8 \pm 3.4^{\star *}$ \\
\hline ANOVA $^{*}$ & & & & & \\
\hline F-ratio & 14.14 & 2.13 & 1.42 & 4.95 & 3.67 \\
\hline P-value & $<0.001$ & 0.15 & 0.29 & $<0.05$ & $<0.05$ \\
\hline
\end{tabular}

*An ANOVA analysis provided the F-ratio and P-value with $95 \%$ confidence level. Numbers in bold type denote a significant effect for the corresponding factor

**Denotes a statistically significant difference with $95 \%$ confidence level using a LSD analysis. 